\title{
Effect of Conservation Agriculture on Soil Physical Health
}

\author{
Vikas Rai ${ }^{1 *}$, Pragati Pramanik ${ }^{1}$, Pramila Aggarwal', \\ Prameela Krishnan $^{1}$ and Ranjan Bhattacharyya ${ }^{2}$ \\ ${ }^{1}$ Division of Agricultural Physics, ICAR-Indian Agricultural Research Institute, \\ New Delhi, India \\ ${ }^{2}$ Center for Environment Science and Climate Resilient Agriculture, ICAR-Indian Agricultural \\ Research Institute, New Delhi, India \\ *Corresponding author
}

\begin{tabular}{|l|}
\hline K e y w o r d s \\
$\begin{array}{l}\text { Conservation } \\
\text { agriculture, Zero } \\
\text { tillage, Hydrothermal } \\
\text { regimes, Climate } \\
\text { change, Conventional } \\
\text { tillage }\end{array}$ \\
\hline Article Info \\
\hline $\begin{array}{l}\text { Accepted: } \\
\text { 04 January } 2018 \\
\text { Available Online: } \\
\text { 10 February } 2018\end{array}$ \\
\hline
\end{tabular}

\section{Introduction}

Tillage intensive and highly mechanized traditional agriculture production system has been identified responsible for soil erosion

\section{A B S T R A C T}

Anthropogenic activities have been the main cause of perceived global warming later in the middle of 20th century. Tillage intensive and highly mechanized traditional agriculture production system has been identified responsible for soil erosion hazards, surface and groundwater pollution, and more water consumption. As a result, the agricultural production system is becoming unsustainable. To achieve the food security of an ever growing population and alleviate poverty besides maintaining agricultural sustainability in the existing situation of degrading natural resources, undesirable effects of climatic inconsistency, rising price of inputs and unstable market prices of food, most of the Asian countries have to face these major challenges. As a result, a drastic change in agricultural practices is required for achieving desirable productivity while nourishing the natural resources. In this situation, to address the sustainability of agriculture globally, the concept of Conservation agriculture (CA) evolved. CA system is very effective natural physical protection against weather (rainfall, wind, dry or wet periods) and improving soil physical health like reducing bulk density (BD) and penetration resistance (PR), increasing hydraulic conductivity and infiltration rate. CA adaptation can improve soil aggregation and soil organic carbon storage. Retention of crop residue on soil surface can moderate soil hydrothermal regimes. With the adoption of CA, environment becomes more healthy and sustainable through maintaining of environmental integrity and services for wider community because of reduced fossil fuels use, less pesticides, and other chemicals consumption. It guards surface and ground water from pollution and similarly alleviates negative climate change effects. Henceforth, CA offers outstanding soil fertility and as well reduces money, time and fossil-fuel consumption. CA system is an effective substitute to conventional agriculture, reducing its disadvantages. 
energy efficiency and contribution to global warming (Boatmann et al., 1999). Anthropogenic activities have been the main cause of perceived global warming later in the middle of 20th century. The fifth Intergovernmental Panel on Climate Change (IPCC) assessment report established that each of the last three decades has been continuously warmer earth's surface than any previous decade since 1850 (IPCC, 2014). As a result, the agricultural production system is becoming unsustainable. Global agro-food outlook has been recently reshaped by two landmark agreements, i.e. the Sustainable Development Goals (in 2012) and the Paris Climate Change Agreement (in November 2015). The challenge is hunger eradication and fair exploitation of terrestrial ecosystems keeping global warming below $2^{\circ} \mathrm{C}$ by 2030 . To achieve the food security of an ever growing population and alleviate poverty besides maintaining agricultural sustainability in the existing situation of degrading natural resources, undesirable effects of climatic inconsistency, rising price of inputs and unstable market prices of food, most of the Asian countries have to face these major challenges. Besides the above mentioned challenges, soil erosion, declining soil organic matter, Stalinizations are making the situation more intense. These are triggered mostly by intensive tillage induced soil organic matter decline, soil structural degradation, water and wind erosion, reduced water infiltration rates, surface sealing and crusting, soil compaction, insufficient return of organic material, and continuous monocropping.

As a result, a drastic change in agricultural practices is required for achieving desirable productivity while nourishing the natural resources. In this situation, to address the sustainability of agriculture globally, the concept of Conservation agriculture (CA) evolved. In the recent FAO (2012) reported that the area under CA has sharply increased worldwide which cover about $\sim 8 \%$ of the total world arable land (124.8 M ha). The adoption of soil conservation practices is one of the tools that the farmers could exploit to implement mitigation climate change policies, while achieving environmental, social and economic benefits. In recent years, awareness has grown that CA can play an important role in achieving the main objectives of doubling the farmer income in long run. The reform requires a production process that respects the environment and uses available knowledge and technology to optimize current production, while preserving natural resources to the benefit of the future generations. The origins of this production method were first introduced in USA in the 1930s - to tackle the soil desertification problem caused by water and wind erosion (Holland, 2004). CA was introduced by the FAO (2008) as a concept of resource-efficient agricultural crop production system based on integrated management of soil, water, and biological resources combined with external inputs (Reicosky, 2015). Henceforth, conservation agriculture (CA) is a method to cultivate annual and perennial crops, based on no vertical disturbance of soil (zero and reduced tillage), with crop residue retention on soil surface and raising cover crops for providing permanent soil cover to naturally increase the organic matter content of soil profile.

\section{Conservation agriculture definition and goals}

Conservation agriculture is a crop production system that retains a permanent soil cover through retention of crop residues on soil surface with no till/zero and reduced tillage in order to enhance the natural biological processes above and below the ground. As per Dumanski et al., (2006), CA is not a "business as usual" approach which is based on increasing crop yields while exploiting natural resources, rather, it aims in achieving 
optimized crop yields and profits besides maintaining a balance among agricultural, economic and environmental issues like reduced input and labor costs. With the adoption of CA, environment becomes more healthy and sustainable through maintaining of environmental integrity and services for wider community because of reduced fossil fuels use, less pesticides, and other chemicals consumption. According to FAO, CA is to achieve acceptable profits, high and sustained production levels, and on serve the environment. It helps in recovering the soil degradation caused by traditional agricultural practices like intensive tillage, burning/removal of previous crop residues and continuous monocropping. It can similarly be mentioned as resource conservation technology (RCT). Traditional agriculture production systems involve a total paradigm alteration with respect to management of soil, crops, nutrients, water, weeds, and farm machinery (Table 1). CA system is a way of organizing agricultural ecosystems for continued and greater productivity, augmented profits and similarly food security besides protecting and improving natural resource base and environment. CA is characterized by four key principles, viz., minimum soil disturbance, permanent or semi-permanent organic soil cover, diversification of crops grown in sequences and/or associations and controlled traffic.

\section{Minimum soil disturbance}

Although tillage reduces surface compaction but it is itself a major factor responsible for subsurface compaction, principally when repeated passes of a heavy tractor on soil (with water content in friable range) are made during seedbed preparation. Zero tillage reduces significantly the number of passes over field and consequently soil compaction. Bautista et al., (1996) reported that in semiarid region, zero-tillage along with mulch reduced bulk density (BD) significantly and resulted in higher infiltration rate (Shaver et al., 2002; Sayre and Hobbs 2004). Kassam and Friedrich (2009) reviewed that soils having more biological activity in minimum tillage with residue retention produces very stable aggregates with well proportion of various sizes of pores, allowing water infiltration and air movement. Such processes known as "biological tillage" and are not compatible with mechanical or conventional tillage. Minimal soil disturbance contributes optimum proportions of macro and micro pores in active rooting-zone, with moderate organic matter decomposition rate, more porous for water movement, retention and release of nutrients and limits the re-exposure of weed seeds and their germination and reduced evaporation, which led to the adoption of conventional tillage (CT) on large scale after the 1930s dust bowl problem in USA. Research since that time has presented the importance of surface residue retention on soil water conservation and reduction in water and wind erosion.

\section{Permanent or semi-permanent organic soil cover}

Unger et al., (1988) reviewed the role of surface residues on water conservation and presented the strong relationship between surface residues and enhanced water infiltration. In a long term study (8-10 years) conducted by Bissett and O'Leary (1996) on cracking clay and a sandy loam soils of southeastern Australia, had reported that under CA with zero and subsurface tillage plus residue retention, infiltration of water was always higher compared to conventional tillage (CT) with frequent plowing plus no residue retention. Kumar and Goh (2000) investigated the effect of crop residues and management practices on soil physical quality, soil nutrient dynamics and crop yield. They reported that residues of cultivated crops act as a significant 
factor in crop production having crucial effects on soil physical, chemical and biological properties as well as water and soil quality. They also opined that residue retention has both positive and negative effects, and the role of agricultural scientists is to enhance their positive effects. Cover crops contribute to the accumulation of organic matter in the surface soil horizon (Roldan et al., 2003; Alvear et al., 2005; Diekow et al., 2005; Madari et al., 2005; Riley et al., 2005), and this effect is increased when combined with no tillage (NT). Mulch also helps in recycling of nutrients, especially when legume cover crops are used, through the association with below-ground biological agents and by providing food for microbial populations. Ghosh et al., (2010) reported on working in north eastern India that a permanent soil cover is vital for protecting the soil from the beating action of raindrops and direct sun shine effect and for enhancing the micro and macro organisms population in the soil with a constant supply of "nutrients"; and in altering the microclimate of the soil and for providing optimal environments for growth and development of soil organisms, including plant roots. Residue retention improves soil aggregation and soil structure, soil biological activity, and biodiversity and carbon sequestration.

\section{Diversification of crops grown in sequences and/or associations}

Howard (1996) reviewed the plant disease control method through diversified crop rotation. The rotation of diverse crops having dissimilar rooting configurations along with zero-till systems helps in developing more extensive root system and macro pores in the soil. This improvement in soil increases water infiltration to deeper soil depths. Because diversified crop rotations surge microbial diversity, the peril of disease and pests occurrences is as well reduced, since the biological diversity helps in keeping check in pathogenic organisms (Leake et al., 2003). Dumanski et al., (2006) opined that not only diversified crop rotation is required for diet supply to the soil micro-organism but extensive root network helps in exploring nutrients from deeper soil layers which becomes useful for successive crops in the season. Moreover, a diversified croprotation as well increases soil flora and fauna diversity. It was also found that cropping sequence and rotations involving legumes helps in minimal rates of build-up of population of pest species, through life cycle interruption, biological nitrogen fixation (BNF), control of off-site pollution and improving biodiversity (Kassam and Friedrich, 2009).

\section{Controlled traffic}

The FAO now consider 'controlling in-field traffic' as a component of CA for following field traffic on permanent track. This is possible if ridge till or permanent beds are used for growing crops Iqbal et al., (2005) reported that NT in dry land environments of Pakistan yields lower than CT. Garcia-Torres et al., (2003) Review from different sources and stated that CA system enhances yield, reduces water requirements, lowers input costs but they have opined that systematic studies are required for analyzing the benefits of CA as the perfomances of CA system is very site specific CA-based systems accomplish better yield, lower water and energy requirements, soil health system resilience, and sustainability in long-run in term. (Connor et al., 2003; Gathala et al., 2011a,b; Hobbs, 2007; Jat et al., 2014; Jat et al., 2014; Saharawat et al., 2010).

Conservation farming components and practices are

No-tillage, minimum and reduced tillage Drip /trickle/sprinkler irrigation technology 
Nutrient recycling as of forest

Crop and pasture rotation.

Agro-forestry or farm forestry

No burning of crop residues

Trap cropping for insect control

Alley cropping

Biological mode of pathogen control

Bed and furrow planting

Integrated pest management (IPM)

Contour farming and strip cropping

Cover and green manure cropping

Organic and biodynamic farming

Stubble mulching

Continuous crop land use

\section{Management aspects of conservation farming include}

Longer term planning and commitment to sustainability

Understanding soil, plant and animal interactions

Commitment to learning and developing a workable system

Rotations and integrating crops, pastures and livestock

Skills in mulch management, weed control and herbicide use

Specialised or modified planting machinery

Skills in soil nutrient and pest management

Developing waste lands through high efficiency pressurized irrigation systems

\section{Conservation farming systems are designed to}

Reduce soil erosion and land degradation through mulch cover
Reduce fuel and labour inputs

Reduce soil temperature and conserve moisture

Achieve viable and sustainable productivity

Increase organic matter and improve soil structure and fertility

Improve yields over the long term

Enhance soil health through increase soil biodiversity

Reduce vulnerability to climate change

Reduce $\mathrm{CO}_{2}$ emissions and build carbon levels

Improve environmental and social outcomes in terms of cleaner air and water and more resilient and stronger communities.

Coverage of conservation agriculture in world and India

CA production systems are used throughout the world. At present, CA is practiced on about 157 million ha, or on about 11 percent of the 1400 million ha of arable land worldwide (https://en.wikipedia.org/wiki/ Arable_land (1 Nov 2017)). Mainly in North and South America (around $76.9 \%$ of the worldwide CA area i.e $34.5 \%$ and $42.4 \%$ respectively) - corresponding to about $11 \%$ of field cropland (FAO, 2017, Fig. 1 and Table 2). There are currently over 10 Mha of arable cropland under CA system in Asia, corresponding to about $6.5 \%$ of the worldwide CA area - mainly located in China $(65.4 \%$ of the total Asian CA area) followed by Kazakhstan (19\%) and India (around 15\%)(FAO, 2017). Various studies have reported (Bash et al., 2015; Kertész and Madarász, 2014; Friedrich et al., 2012) that the worldwide adoption of CA systems has 
increased at an average rate exceeding 7 $\mathrm{Mha} / \mathrm{yr}$, compared to the past millennium, and at the rate of some $10 \mathrm{Mha} / \mathrm{yr}$ since 2008/2009 (Kassam et al., 2015). While in 1973/74 the system was used only on $2.8 \mathrm{M}$ ha worldwide, the area had grown in 1999 , to $45 \mathrm{M}$ ha, by 2003 the area had grown to $72 \mathrm{M}$ ha and by 2009 it was 117 Mha. In the last 11 years CA system has expanded at an average rate of more than $6 \mathrm{M}$ ha per year showing the increased interest of farmers in this technology, mainly in North and South America and in Australia and New Zealand, and more recently in Asia where large increases in the adoption of CA are expected. The concept of conservation agriculture is relatively new in Asia. In Asia, a large share of the conservation agriculture is confined in India, and that is in the Indo Gangetic plain.

Earlier, way back in early 1980s, attempts were made for zero tillage (dry seeding) as a part of 'vertisol technology' launched by the International Crops Research Institute for the Semi-Arid Tropics (ICRISAT). In recent times, the concept of zero tillage (and also conservation agriculture) has been well tested, perfected and widely adopted in irrigated areas of Indo-Gangetic plain. The progressive adoption of conservation agriculture in IndoGangetic plain is given in Figure 1 (Jat et al., 2008). The area under zero tillage in IndoGangetic plains of India was estimated to be 1.90 million hectare in 2005 , which increased to 2.5 million hectares in 2007 .

\section{Potential benefits of CA}

CA aims to make improved use of agricultural inputs through the combined management of accessible soil, water and biological resources, joint with restricted external inputs. It pays to environmental maintenance and to sustainable agricultural production by keeping a permanent or semi-permanent organic soil cover. Implementation of CA at the farm scale is accompanied with lesser labour and farm power inputs, added stable yields and enhanced soil nutrient efficiency. Crop production profitability under $\mathrm{CA}$ tends to increase over time relative to conventional agriculture. Other benefits credited to $\mathrm{CA}$ at the watershed level link to more regular surface hydrology and reduced sediment loads in surface water. At the global level, CA sequesters carbon, thus decreasing $\mathrm{CO}_{2}$ in the atmosphere and helping to check climate change. It also conserves soil and terrestrial biodiversity. Potential benefits of CA are:

Improvement of physical, chemical and biological condition, thus soil quality (Gathala et al., 2011b)

Improvement in $\mathrm{C}$ sequestration and build-up in SOM, thus helps in mitigation of Green House Gas emissions and make the production system more resilient to climate change related irregularities (Saharawat et al., 2012)

Decrease weeds incidence like Phalaris minor in wheat (Malik et al., 2005)

Increase in water and nutrient use efficiency (Jat et al., 2012);

Improvement in production and productivity (4\% to 10\%) (Gathala et al., 2011a);

Advanced sowing date (Malik et al., 2005);

Decrease greenhouse gas (GHGs) emission and better environmental sustainability (Pathak et al., 2011);

Retention of crop residue on soil lessens nutrients loss, and environmental pollution because of avoidance of residue burning (Sidhu et al., 2007);

Better crop diversification (Jat et al., 2005). 
Table.1 Comparison of conventional and conservation agriculture systems (Sharma et al., 2012.)

\begin{tabular}{|c|c|c|}
\hline S.No & Conventional agriculture & Conservation agriculture \\
\hline 1. & $\begin{array}{l}\text { Cultivating land, using science and } \\
\text { technology to dominate nature }\end{array}$ & Least interference with natural processes \\
\hline 2. & $\begin{array}{c}\text { Excessive mechanical tillage and soil } \\
\text { erosion }\end{array}$ & $\begin{array}{l}\text { No-till or drastically reduced tillage } \\
\text { (biological tillage) }\end{array}$ \\
\hline 3. & High wind and soil erosion & Low wind and soil erosion \\
\hline 4. & $\begin{array}{l}\text { Residue burning or removal (bare } \\
\text { surface) }\end{array}$ & $\begin{array}{l}\text { Surface retention of residues } \\
\text { (permanently covered) }\end{array}$ \\
\hline 5. & Water infiltration is low & Infiltration rate of water is high \\
\hline 6. & Use of ex-situ FYM/composts & Use of in-situ organics/composts \\
\hline 7. & Green manuring (incorporated) & $\begin{array}{l}\text { Brown manuring/cover crops (surface } \\
\text { retention) }\end{array}$ \\
\hline 8. & $\begin{array}{l}\text { Kills established weeds but also } \\
\text { stimulates more weed seeds to } \\
\text { germinate }\end{array}$ & $\begin{array}{l}\text { Weeds are a problem in the early stages } \\
\text { of adoption but decrease with time }\end{array}$ \\
\hline 9. & $\begin{array}{l}\text { Free-wheeling of farm machinery, } \\
\text { increased soil compaction }\end{array}$ & $\begin{array}{l}\text { Controlled traffic, compaction in } \\
\text { tramline, no compaction in crop area. }\end{array}$ \\
\hline 10. & $\begin{array}{l}\text { Mono cropping/culture, less efficient } \\
\text { rotations }\end{array}$ & Diversified and more efficient rotations \\
\hline 11. & $\begin{array}{l}\text { Heavy reliance on manual labor, } \\
\text { uncertainty of operations }\end{array}$ & $\begin{array}{l}\text { Mechanized operations, ensure timeliness } \\
\text { of operations }\end{array}$ \\
\hline 12. & $\begin{array}{l}\text { Poor adaptation to stresses, yield losses } \\
\text { greater under stress conditions }\end{array}$ & $\begin{array}{l}\text { More resilience to stresses, yield losses } \\
\text { are less under stress conditions }\end{array}$ \\
\hline 13. & $\begin{array}{l}\text { Productivity gains in long-run are in } \\
\text { declining order }\end{array}$ & $\begin{array}{l}\text { Productivity gains in long-run are in } \\
\text { incremental order }\end{array}$ \\
\hline
\end{tabular}

Table.2 Extent of adoption of conservation agriculture worldwide (> 100,000 ha) (FAO, 2016)

\begin{tabular}{|c|c|c|c|c|c|}
\hline Country & CA area (ha) & Country & CA area (ha) & Country & $\begin{array}{c}\text { CA area } \\
\text { (ha) }\end{array}$ \\
\hline USA & $\mathbf{2 6 , 5 0 0 , 0 0 0}$ & Bolivia & $\mathbf{7 0 6 , 0 0 0}$ & New Zealand & $\mathbf{1 6 2 , 0 0 0}$ \\
\hline Argentina & $\mathbf{2 5 , 5 5 3 , 0 0 0}$ & Uruguay & $\mathbf{6 5 5 , 1 0 0}$ & Finland & $\mathbf{1 6 0 , 0 0 0}$ \\
\hline Brazil & $\mathbf{2 5 , 5 0 2 , 0 0 0}$ & Spain & $\mathbf{6 5 0 , 0 0 0}$ & U. Kingdom & $\mathbf{1 5 0 , 0 0 0}$ \\
\hline Australia & $\mathbf{1 7 , 0 0 0 , 0 0 0}$ & Ukraine & $\mathbf{6 0 0 , 0 0 0}$ & Zimbabwe & $\mathbf{1 3 9 , 3 0 0}$ \\
\hline Canada & $\mathbf{1 3 , 4 8 1 , 0 0 0}$ & S. Africa & $\mathbf{3 6 8 , 0 0 0}$ & Mozambique & $\mathbf{1 5 2 , 0 0 0}$ \\
\hline Russia & $\mathbf{4 , 5 0 0 , 0 0 0}$ & Venezuela & $\mathbf{3 0 0 , 0 0 0}$ & Colombia & $\mathbf{1 2 7 , 0 0 0}$ \\
\hline China & $\mathbf{3 , 1 0 0 , 0 0 0}$ & France & $\mathbf{2 0 0 , 0 0 0}$ & Others & $\mathbf{4 0 9 , 4 4 0}$ \\
\hline Paraguay & $\mathbf{2 , 4 0 0 , 0 0 0}$ & Zambia & $\mathbf{2 0 0 , 0 0 0}$ & India & $\mathbf{2 0 , 0 0 , 0 0 0}$ \\
\hline Kazakhstan & $\mathbf{1 , 6 0 0 , 0 0 0}$ & Chile & $\mathbf{1 8 0 , 0 0 0}$ & Total & $\mathbf{1 1 2 , 7 5 5 , 1 0 0}$ \\
\hline
\end{tabular}


Table.3 The amount of organic $\mathrm{C}\left(\mathrm{Mg} \mathrm{ha}^{-1}\right)$ under zero-till, residue retention and wheat-maize crop rotation (CA), and conventional tillage with crop removal and maize monoculture (CT) between 1996 and 2006 (Dendooven et al., 2012)

\begin{tabular}{|c|c|c|}
\hline Year & CT $\left(\mathrm{Mg} \mathrm{ha}^{-1}\right)$ & CA $\left(\mathrm{Mg} \mathrm{ha}^{-1}\right)$ \\
\hline 1996 & 1.80 & 8.87 \\
\hline 1997 & 2.71 & 7.83 \\
\hline 1998 & 2.36 & 10.83 \\
\hline 1999 & 0.48 & 6.54 \\
\hline 2000 & 2.34 & 10.40 \\
\hline 2001 & 0.85 & 8.86 \\
\hline 2002 & 2.35 & 11.83 \\
\hline 2003 & 1.16 & 9.74 \\
\hline 2004 & 1.43 & 10.27 \\
\hline 2005 & 2.48 & 10.24 \\
\hline 2006 & 2.30 & 9.38 \\
\hline
\end{tabular}

Table.4 Nutrient content in conservation tillage (NT) in comparison to conventional tillage (CT)

\begin{tabular}{|c|c|c|c|c|c|c|}
\hline \multirow{2}{*}{ Soil depth (cm) } & \multicolumn{3}{|c|}{ Carbon (\%) } & \multicolumn{2}{c|}{ Nitrogen (\%) } & \multicolumn{2}{c|}{ Phosphorus (\%) } \\
\cline { 2 - 7 } & NT & CT & NT & CT & NT & CT \\
\hline $0-5$ & 2.5 & 1.0 & 0.3 & 0.1 & 100 & 20 \\
\hline $10-15$ & 1.3 & 1.0 & 0.2 & 0.1 & 10 & 40 \\
\hline
\end{tabular}

Source: Conservation Technology Information, CTIC Partners, 2000

Table.5 Average energy consumption of some tillage operations (John Nalewaja, 2001)

\begin{tabular}{|c|c|c|}
\hline Operations & Diesel consumption (l/ha) & Energy consumption (kcal/ ha) \\
\hline Mouldboard plough & 16.81 & 256,669 \\
\hline Cultivator & 5.61 & 52,285 \\
\hline Disk harrow & 6.55 & 61,046 \\
\hline "Chisel" plough & 8,89 & 82,855 \\
\hline Harrow & 3.37 & 30,476 \\
\hline Pass with no soil tillage & 0.94 & 8,761 \\
\hline
\end{tabular}


Table.6 Emission of greenhouse gases in wheat and rice with different technological options in the upper Indo-Gangetic Plains (Pathak and Aggarwal, 2012)

\begin{tabular}{|c|c|c|}
\hline Technology & \multicolumn{2}{|c|}{ Total GWP $\left(\left(\mathrm{kg} \mathrm{CO}_{\mathbf{2}} \mathbf{h a}^{-1}\right)\right.$} \\
\hline Conventional tillage & Wheat & Rice \\
\hline Sprinkler irrigation & 1808 & 2934 \\
\hline Zero tillage & 1519 & 735 \\
\hline Integrated nutrient management & 111 & 346 \\
\hline Organic wheat/rice & -171 & 6089 \\
\hline Nitrification inhibitor & -1880 & 8569 \\
\hline Site-specific nutrient management & 1663 & 2461 \\
\hline Straw fed to cattle & 1696 & 2794 \\
\hline New cultivar & 1824 & 3877 \\
\hline Yield maximization & 2056 & 2599 \\
\hline
\end{tabular}

Enhancement of resource use efficiency (Jat et al., 2009a).

Surface residue retention controls weeds, moderate soil temperature, decrease evaporation, and increase biological activity (Gathala et al., 2011b).

\section{CA and Carbon Sequestration:}

Conservation agriculture is getting worldwide attention as an alternate technology to restore soil organic carbon (SOC, Table 3). Further $\mathrm{CA}$ by restoring $\mathrm{SOC}$, it can help in maintaining environmental quality and developing sustainable agricultural production system. Improved SOC means better soil organic matter (SOM) and henceforth offers improved soil health (Dendooven et al., 2012). Carbon levels in soil are determined by the balance of inputs, such as crop residues, organic amendments, and $\mathrm{C}$ losses through organic matter decomposition.

\section{CA and soil physical health}

Effects of CA on soil properties show spatiotemporal changes and these changes are specific to the certain system chosen. Anikwe and Ubochi (2007) reported that high soil surface coverage by No-till (NT) systems showed no significant variation in soil properties, particularly in the upper few centimeters of soil surface. Voorhees and Lindstrom (1984) revealed that porosity, bulk density (BD), and mean weight diameter (MWD) of soil aggregates improved from the time of start of a tillage trial in both CA and conventional tillage.

Bulk density, soil compaction, soil structure and soil hydraulic parameters

Bulk density is a significant soil physical factor which is used greatly to assess soil compactness. The bulk density varies largely with inherent soil qualities as well as with management. Fabrizzi et al., (2005) and Gantzer and Blake (1978) have reported higher $\mathrm{BD}$ and penetration resistance (PR) values under ZT compared with CT. In semiarid regions, Bautista et al., (1996) observed that ZT with residue decreased bulk density (BD) considerably. Sayre and Hobbs 2004 have conceptualized that use of ZT along with a permanent residue retention, though $\mathrm{BD}$ was higher, showed greater infiltration rate under NT systems because of more stable soil structures (high MWD of aggregates) in the ZT system more number of uninterrupted 
earthworm networks that linked to the soil surface.. Many researchers have found that continuous use of zero, reduced and shallow tillage would necessitate a change to temporary CT to correct soil problems. Several researchers (Pikul et al., 1990; Sauer et al., 1990) have publicized that, on few soils, moving from a plowed cropping system to a ZT system caused an increase in BD and decline in porosity.

As per Lal et al., (2007), ZT are beneficial in decreasing soil and crop residue disturbance, controlling soil evaporation and lessening erosion losses. More stable aggregates in the upper surface of soil have been associated with no-till soils than tilled soils and this correspondingly results in high total porosity under NT plots. It has been also found that ZT did not only increase aggregate stability but then again also improved SOM inside the aggregates. Kargas et al., (2012) witnessed that ZT plots preserve more water than CT plots. They as well described that in ZT, soil pore system improved by increasing larger storage pores $(0.5-50 \mathrm{~mm})$ and transmission pores $(50-500 \mathrm{~mm})$. They also found that greater micro porosity in ZT caused an increase in soil water content and subsequently plant available water in $0-10 \mathrm{~cm}$ soil.

Therefore, to improve soil water storage and increase water use efficiency (WUE) most researchers have proposed replacement of traditional tillage with conservation tillage. It has been reported that WUE has been greater in ZT soils systems as compared with CT (Fabrizzi et al., 2005; Silburn et al., 2007). Su et al., (2007) found that the soil water storage quantity using ZT was $25 \%$ higher than CT during a six year study while WUE was significantly higher in ZT than CT and RT. On a sandy Alfisol in south western Nigeria, Busari and Salako (2012) observed higher unsaturated water flow parameters and infiltration rate under CT and MT than ZT at the end of the first year of the study but at end of the second year, ZT had higher infiltration parameters compared with $\mathrm{CT}$ as it may be due to the fast draining macro-pores (FDP) created by CT could facilitate infiltration momentarily after tillage, but these FDP reduced with time as a result of repackaging of soil aggregates (Martınez et al., 2008), leading to a lower infiltration rate under CT than ZT overtime. Several other studies (Pikul and Aase, 1995; Shukla et al., 2003) have found that because of the protection of the soil surface and effect of SOC, there is higher infiltration rates under NT than $\mathrm{CT}$.

Under conservation tillage, higher water content in the top soil and more plant residues on the soil surface, resulting in declined evaporation, have been linked with the lower soil temperature (Rasmussen et al., 1999). A higher evapotranspiration (ET) in NT plots than in CT and RT plots has also been reported and was attributed to greater and deeper soil water storage (Su et al.,2007) as extensive tillage usually expose soil surface to water loss and evaporation.

Using the stable isotope technique, Busari et al., (2013) reported that soil water stable isotopes $\left({ }^{\delta 18} \mathrm{O}\right.$ and $\left.{ }^{\delta} \mathrm{D}\right)$ were more enriched near the soil surface under CT compared with ZT indicating more evaporation under conventionally tilled soils.

Mulches alter soil hydrothermal characteristics in root zone, preserve soil moisture suppress weeds growth and encourage soil productivity. Different kind of crop residue mulches vary in their ability to conserve soil moisture, regulate soil temperature, weed control, soil salinity control, nutrients availability and soil physical properties which leads to the variations in crop plant yield (Anderson and Jensen, 2001). 


\section{Soil hydrological and thermal properties}

Soil temperature is considered as one of the most important factors that affect the soil heat storage, soil water flux, and soil heat flux, seed emergence, nutrient transformation, and transport, uptake and plant growth. The functional activity of plant roots can be affected both at low and high soil temperatures. It has been found that favorable soil temperature for the growth of nitrogen fixing bacteria generally ranges between 20 to $25{ }^{\circ} \mathrm{C}$. The optimum soil temperature varies from $25-30{ }^{\circ} \mathrm{C}$ for sorghum and rice, $15-27^{\circ} \mathrm{C}$ for wheat, and $25-35^{\circ} \mathrm{C}$ for corn crop (Oswal et al., 1993). Candido and Miccolis (2003) has studied that mulching has positive effect on the soil plant system: soil temperature good weed control, reducing evaporative humidity, and earliness effects on yield with better qualitative and quantitative traits. Mulch helps to attain greater soil temperatures than the uncovered ridges (Graefe et al., 2005). Mulches by modifying the soil thermal regime and above ground temperature may affect plant growth, development, and crop production (Likatas et al., 1986).

Likatas et al., (1986) considers temperature is probably the utmost significant factor among the various environmental factors. Soil temperature is the measure of the intensity of heat in soil. Thermal properties of soils regulate microclimate, which has direct impact on seed germination, seedling emergence, root growth and subsequent crop establishment (Fan et al., 2012). They have also reported that crops encounter sub or supra-optimal temperature at some stages of crop growth periods. Surface application of wheat straw at 7.5 tonnes/ha reduced the maximum soil temperature from 37.1 to $28.6^{\circ} \mathrm{C}$. The soil temperature was lower for all the layers under residue mulch (Kalra et al., 1984). Similarly, soil temperature (ST) under different manure types were of the order charcoal + compost > no manure >green manure. ST of surface under transparent polythene was $5-6{ }^{\circ} \mathrm{C}$ higher value over no polythene but these differences narrowed down with increase in depth (Maity, 2008; Maity and Aggarwal, 2012; Pramanik et al., 2015). Similar type of result was also previously observed by Wilson and Jasa (2007).

\section{Improving water use efficiency (WUE) and nutrient use efficiency (NUE)}

Aggarwal and Goswami (2003) and Aggarwal et al., (2006) described that bed-planting method was better than conventional planting method as it enhanced water and nutrient use efficiency as well as decreased mechanical impedance besides better root growth. Fahong and Sayre (2004) also observed that nitrogen use efficiency (NUE) enhanced by $10 \%$ or more in furrow irrigated bed-planting systems due to improved microclimate reduced canopy humidity inside the field leading to reduced crop lodging and decreased disease incidence. Soil nutrient supplies and recycling are increased because of enhanced decomposition of organic crop residues in soil (Table 4). Incorporation of nitrogen-fixing legume crops in rotation meets considerable amount nitrogen requirement of food crops, though other essential nutrients must be added by other chemical and/or organic fertilizer.

\section{Environmental benefits}

CA signifies environmental friendly technologies. Since it uses resources more competently than traditional agriculture making resources available for other uses, as well as conserving them for coming generations. The substantial decrease in fossil fuel usage under ZT agriculture marks in smaller amount greenhouse gases release into atmosphere and cleaner air as a whole. A 
lesser use of agrochemicals in CA moreover considerably lessens pollution in air, soil and water. Average energy and diesel consumption in mould board tillage is much higher than other tillage operation (Table 5). In global warming potential view point, emission of greenhouse gases are higher under conventional tillage as compare to zero tillage both under rice and wheat (Table 6). CA practices save time, fuel, labor, cost, energy and water as compare to conventional practices (Figure 2).

CA is currently recognized internationally as the utmost significant technologies having potential to decrease the influences of agriculture, increase and look after the natural resource, regulates carbon dioxide productions. CA can help in climate change adaptation by enhancing systems resilience and therefore making the system less susceptible to climatic aberrations; improved SOM, soil structure and water storage helps in reducing flood and erosion, drought effect; providing sustained yield and reducing greenhouse gas emission.

CA can be adopted as an emerging technology because of efficient residue management, ZT, well-organized management of inputs. Precision farming, effective management of water, and renewal of deteriorated soils all can lead to sustainable agriculture. Soil tillage operations are important to regulate carbon content in soils since they have impact on soil carbon dynamics. Tillage operations influences surface soil condition, decreases SOC by accelerating the degradation and mineralization of biomass because of more aeration and churning of plant residues in soil, revealing earlier protected SOC inside the soil aggregates to soil fauna, and by increasing soil erosional losses. Equally, long-term ZT or reduced tillage can improve SOC of soil surface layer by means of numerous interrelating causes like improved residue return, less mixing and soil disturbance, greater SOC, moderated soil temperature, production of root growth as well as biological activity, and reduced hazards of soil erosion.

\section{References}

Aggarwal, P., and Goswami, B. 2003. Bed planting system for increasing water-use efficiency of wheat (Triticum aestivum) grown on Inceptisol (Typic Ustochrept). Indian journal of agricultural science, 73(8), 422-425.

Aggarwal, P., Bhattacharyya, R., Mishra, A. K., Das, T. K., Šimůnek, J., Pramanik, P and Kamble, K. H. 2017. Modelling soil water balance and root water uptake in cotton grown under different soil conservation practices in the Indo-Gangetic Plain. Agriculture, Ecosystems and Environment, 240, 287-299.

Aggarwal, P., Choudhary, K. K., Singh, A. K., and Chakraborty, D. 2006. Variation in soil strength and rooting characteristics of wheat in relation to soil management. Geoderma, 136(1), 353-363.

Allmaras, R. R., Rickman, R. W., Ekin, L. G., and Kimball, B. A. 1977. Chiselling influences on soil hydraulic properties. Soil Science Society of America Journal, 41, 796-803.

Alvear, M., Rosas, A., Rouanet, J. L., and Borie, F. 2005. Effects of three soil tillage systems on some biological activities in an Ultisol from southern Chile. Soil and Tillage Research, 82(2), 195-202.

Anderson, D. T., and Russell, G. C. 1964. Effects of various quantities of straw mulch on the growth and yield of spring and winter wheat. Canadian Journal of Soil Science, 44(1), 109-118.

Anderson, M. K., and Jensen, L. S. 2001. Low soil temperature effects on short-term gross $\mathrm{N}$ mineralisation-immobilisation turnover after incorporation of a green manure. Soil Biology and Biochemistry, 33(4), 511-521.

Anikwe, M. A. N., and Ubochi, J. N. 2007. Shortterm changes in soil properties under tillage systems and their effect on sweet potato 
(Ipomea batatas L.) growth and yield in an Ultisol in south-eastern Nigeria. Soil Research, 45(5), 351-358.

Ball, B. C., O'sullivan, M. F., and Hunter, R. 1988. Gas diffusion, fluid flow and derived pore continuity indices in relation to vehicle traffic and tillage. Journal of Soil Science, 39(3), 327-339.

Basch, G., Friedrich, T., Kassam, A., GonzalezSanchez, E., 2015. Conservation agriculture in europe. In: Farooq, M., Siddique, K.H.M. (Eds.), Conservation Agriculture. Springer International Publishing, Switzerland, pp. 357-388. http://dx.doi.org /10. 1007/978- 3-319-11620-4_15.

Bautista, S., Bellot, J., and Vallejo, V. R. 1996. Mulching treatment for postfire soil conservation in a semiarid ecosystem. Arid Land Research and Management, 10(3), 235-242.

Benjamin, J. G. 1993. Tillage effects on nearsurface soil hydraulic properties. Soil and Tillage Research, 26(4), 277-288.

Bissett, M. J., and Oleary, G. J. 1996. Effects of conservation tillage and rotation on water infiltration in two soils in south-eastern Australia. Soil Research, 34(2), 299-308.

Boatman, J. F., and Reichel, B. S. 1999. U.S. Patent No. 5,892,690. Washington, DC: U.S. Patent and Trademark Office.

Busari, M. A., and Salako, F. K. 2012. Effect of tillage and poultry manure application on soil infiltration rate and maize root growth in a sandy Alfisol. Agro-Science, 11(2), 2431.

Busari, M. A., Salako, F. K., Tuniz, C., Zuppi, G. M., Stenni, B., Adetunji, M. T., and Arowolo, T. A. 2013. Estimation of soil water evaporative loss after tillage operation using the stable isotope technique. International Agrophysics, 27(3), 257-264.

Butorac, A., and Carter, M. R. 1994. Conservation tillage in eastern Europe. Conservation tillage in temperate agro ecosystems, 357374.

Candido, N. and Miccolis. V. 2003. Greenhouse melon response to plastic mulch. ACTA Horticulture, 458, 263-267. Connor, D. J., Timsina, J., and Humphreys, E. 2003. Prospects for permanent beds for the rice- wheat system. Improving the Productivity and Sustainability of Rice-Wheat Systems: Issues and Impacts, (improving the pro), 197-210.

Dendooven, L., Patiño-Zúñiga, L., Verhulst, N., Luna-Guido, M., Marsch, R., and Govaerts, B. 2012. Global warming potential of agricultural systems with contrasting tillage and residue management in the central highlands of Mexico. Agriculture, Ecosystems and Environment, 152, 50-58.

Derpsch, R., Friedrich, T., Kassam, A., and Li, H. 2010. Current status of adoption of no-till farming in the world and some of its main benefits. International Journal of Agricultural and Biological Engineering, 3(1), 1-25.

Derpsch, R., Friedrich, T., Landers, J. N., Rainbow, R., Reicosky, D. C., Sá, J. C. M., and Weiss, K. (2011, September). About the necessity of adequately defining notillage-a discussion paper. In Proceedings of the 5th World Congress of Conservation Agriculture (pp. 1-4).

Diekow, J., Mielniczuk, J., Knicker, H., Bayer, C., Dick, D. P., and Kögel-Knabner, I. 2005. Soil $\mathrm{C}$ and $\mathrm{N}$ stocks as affected by cropping systems and nitrogen fertilisation in a southern Brazil Acrisol managed under notillage for 17 years. Soil and Tillage Research, 81(1), 87-95.

Dumanski, J., Peiretti, R., Benites, J. R., McGarry, D., and Pieri, C. 2006. The paradigm of conservation agriculture. Proc. World Assoc. Soil Water Conservation, 1, 58-64. Ehlers, W. (1975). Observations on earthworm channels and infiltration on tilled and untilled loess soil. Soil Sci. 119, 242-9.

Ehlers, W., Köpke, U., Hesse, F., and Böhm, W. 1983. Penetration resistance and root growth of oats in tilled and untilled loess soil. Soil and Tillage Research, 3(3), 261275.

Fabrizzi, K. P., Garcia, F. O., Costa, J. L., and Picone, L. I. 2005. Soil water dynamics, physical properties and corn and wheat responses to minimum and no-tillage systems in the southern Pampas of Argentina. Soil and Tillage Research, 81(1), 57-69. 
Fahong, W., Xuqing, W., and Sayre, K. 2004. Comparison of conventional, flood irrigated, flat planting with furrow irrigated, raised bed planting for winter wheat in China. Field Crops Research, 87(1), 35-42.

Fan, J. W., Du, Y. L., Turner, N. C., Li, F. M., and He, J. 2012. Germination characteristics and seedling emergence of switchgrass with different agricultural practices under arid conditions in China. Crop science, 52(5), 2341-2350.

Friedrich, T., Derpsch, R., Kassam, A., 2012. Global overview of the spread of Conservation Agriculture. Field Act. Sci. Rep. 6, 1-7. (Special Issue, Retrieved from:). http://factsreports.revues.org/1941.

Gantzer, C. J., and Blake, G. R. 1978. Physical characteristics of Le Sueur clay loam soil following no-till and conventional tillage. Agronomy Journal, 70(5), 853-857.

Garc1'a-Torres, L., Benites, J., Martı'nez-Vilela, A., Holgado-Cabrera, A., 2003. Conservation Agriculture: Environment, Farmers Experiences, Innovations, Socioeconomy, Policy. Kluwer Academic Publishers, Boston, USA.

Gathala, M. K., Ladha, J. K., Saharawat, Y. S., Kumar, V., Kumar, V., Sharma, P. K. 2011b. Effect of Tillage and Crop Establishment Methods on Physical Properties of a Medium-Textured Soil under a Seven-Year Rice - Wheat Rotation. Soil Science Society of America Journal, 75, 1851-1862.

Gathala, M. K., Ladha, J. K., Saharawat, Y. S., Kumar, V., Kumar, V., and Sharma, P. K. 2011a. Effect of tillage and crop establishment methods on physical properties of a medium-textured soil under a seven-year rice- wheat rotation. Soil Science Society of America Journal, 75(5), 1851-1862.

Ghosh, P. K., Das, A., Saha, R., Kharkrang, E., Tripathi, A. K., Munda, G. C., and Ngachan, S. V. 2010. Conservation agriculture towards achieving food security in North East India. Current Science (Bangalore), 99(7), 915-921.

Graefe, J. 2005. Simulation of soil heating in ridges partly covered with plastic mulch, part I: Energy balance model. Biosystems engineering, 92(3), 391-407.

Ham, J. M., Kluitenberg, G. J., and Lamont, W. J. 1993. Optical properties of plastic mulches affect the field temperature regime. Journal of the American Society for Horticultural Science, 118(2), 188-193.

Hillel, D. (1982) Introduction to soil physics. Academic Press, New York. Hobbs, P. R. 2007. Conservation agriculture: what is it and why is it important for future sustainable food production? The Journal of Agricultural Science, 145(2), 127.

Howard, R. J. 1996. Cultural control of plant diseases: a historical perspective. Canadian Journal of Plant Pathology, 18(2), 145-150. IPCC (2014). Climate Change 2014Synthesis Report. Contribution of Working Groups I, II and III to the Fifth Assessment Report of the Intergovernmental Panel on Climate Change. Core Writing Team, R.K. Pachauri and L.A. Meyer (Eds.). Switzerland: IPCC, Geneva.

Iqbal M., Hassan A.U., Ali A. and Rizwanullah M. 2005.Residual effect of tillage and farm manure on some soil physical properties and growth of wheat (Triticum aestivum L.). Int. J. Agric. and Biol. 7: 54-57.

Jat M. L., Singh, R.G., Saharawat, Y.S., Gathala, M. K., Kumar, V., Sidhu, H.S., and Gupta, R. 2009b. Innovations through conservation agriculture: progress and prospects of participatory approach in the Indo-Gangetic plains. In Pub Lead Papers, 4th World Congress on Conservation Agriculture (pp. 60-64). 4-7 February, 2009, New Delhi India.

Jat, M. L., Gathala, M. K., Ladha, J. K., Saharawat, Y. S., Jat, A.S., Kumar Vipin, Sharma, S. K., Kumar V., and Gupta, R. 2009a. Evaluation of Precision Land Leveling and Double Zero-Till Systems in Rice-Wheat Rotation: Water use, Productivity, Profitability and Soil Physical Properties. Soil and Tillage Research, 105, 112-121.

Jat, M. L., Malik, R.K., Saharawat, Y.S., Gupta, R. Bhag, M., and Raj Paroda. 2012. Proceedings of Regional Dialogue on Conservation Agricultural in South Asia, 
New Delhi, India, APAARI, CIMMYT, ICAR, p 32.

Jat, M. L., Singh, S., Rai, H. K., Chhokar, R.S., Sharma, S.K. and Gupta, R.K. 2005. Furrow Irrigated Raised Bed Planting Technique for Diversification of RiceWheat System of Indo-Gangetic Plains. Journal of Japan Association for International Cooperation for Agriculture and Forestry, 28 (1), 25-42.

Jat, ML, Gupta, RK, Sharma, SK, Gill, MS, Dass $S$ and Singh, RP 2008. Evaluating conservation tillage systems under maizewheat rotaion in Indo-Gangatic plains of Rabi Maize. India (in): Proceedings of the 10th Asian Regional Maize Workshop, Makassar, Indonesia, p. 7.

Jat, R. K., Sapkota, T. B., Singh, R. G., Jat, M. L., Kumar, M., and Gupta, R. K. 2014. Seven years of conservation agriculture in a ricewheat rotation of Eastern Gangetic Plains of South Asia: Yield trends and economic profitability. Field Crops Research, 164, 199-210.

Kalra, N., Sarma, K. S. S., and Nagarajarao, Y. 1984. Modification of hydro-thermal regimes by the application of residue mulch for better water use, root growth and yield of summer mung-bean. Transactions of Indian Society of Desert Technology and University Centre of Desert Studies.

Kargas, G., Kerkides, P., and Poulovassilis, A. 2012. Infiltration of rain water in semi-arid areas under three land surface treatments. Soil and Tillage Research, 120, 15-24.

Kaspar, T. C., Erbach, D. C., and Cruse, R. M. 1990. Corn response to seed-row residue removal. Soil Science Society of America Journal, 54(4), 1112-1117.

Kassam, A. H., and Friedrich, T. 2009. Perspectives on Nutrient Management in Conservation Agriculture. Invited paper, IV World Congress on Conservation Agriculture, 4-7 February 2009, New Delhi, India.

Kassam, A., Friederich, T., Derpsch, R., Kienzle, J., 2015. Overview of the worldwide spread of conservation agriculture. Field Act. Sci. Rep. 8, 1-13. Retrieved from: http://factsreports.revues.org/3966.
Kemper, W.D., Trout, T.J., Segeren, A., and Bullock, M. 1987. Worms and water. Journal of Soil and Water Conservation, 42, 401-404. Kertész, A., Madarász, B., 2014. Conservation agriculture in europe. Int. Soil Water Conserv. Res. 2 (1), 91-96.

Kumar, K. and Goh, K. M. 2000. Crop residues and management practices: effects on soil quality, soil nitrogen dynamics, crop yield and nitrogen recovery. Advance Agronomy, 68, 198-279.

Lal, R., Reicosky, D. C., and Hanson, J. D. 2007. Evolution of the plow over 10,000 years and the rationale for no-till farming. Soil and Tillage Research, 93(1), 1-12.

Leake, A. R. 2003. Integrated pest management for conservation agriculture. In Conservation agriculture: environment, farmers experiences, innovations, socioeconomy, policy (eds L. Garcia-Torres, J. Benites, A. Martinez-Vilelaand A. Holgado-Cabrera), pp. 271-279. Dordrecht, the Netherlands; Boston, Germany; London, UK: Kluwer Academia Publishers.

Liakatas, A., Clark, J. A., and Monteith, J. L. 1986. Measurements of the heat balance under plastic mulches. Part I. Radiation balance and soil heat flux. Agricultural and Forest Meteorology, 36(3), 227-239.

Madari, B., Machado, P. L., Torres, E., de Andrade, A. G., and Valencia, L. I. 2005. No tillage and crop rotation effects on soil aggregation and organic carbon in a Rhodic Ferralsol from southern Brazil. Soil and Tillage Research, 80(1), 185-200.

Maity, P. 2008. Studies on Thermal Properties of soil and modelling of heat conduction under diff erent soil management practices. Ph.D. Thesis. Indian Agricultural research Institute, New Delhi, India.

Maity, P. and Aggarwal, P. 2012. Variation of thermal properties of sandy loam soil under different management practices. Indian Journal of Agricultural Sciences 82(2): 181-185.

Malik, R. K., Gupta, R. K., Singh, C. M., Yadav, A., Brar, S. S., Thakur, T. C., Singh, S. S., Singh, A. K., Singh, R., and Sinha, R. K. (2005). Accelerating the Adoption of Resource Conservation Technologies in Rice Wheat System of the Indo-Gangetic 
Plains. Proceedings of Project Workshop, Directorate of Extension Education, Chaudhary Charan Singh Haryana Agricultural University (CCSHAU), June 1-2, 2005. Hisar, India: CCSHAU.

Martínez, E., Fuentes, J. P., Silva, P., Valle, S., and Acevedo, E. 2008. Soil physical properties and wheat root growth as affected by no-tillage and conventional tillage systems in a Mediterranean environment of Chile. Soil and Tillage Research, 99(2), 232-244.

Oswal M C. 1993. A text book of soil physics. Oxford and IBH Publishing Co. Pvt. Ltd., New Delhi. Pathak, H., and Aggarwal, P. K. 2012. Low carbon technologies for agriculture: a study on rice and wheat systems in the Indo-Gangetic Plains. Indian Agricultural Research Institute, p. xvii, 78.

Pathak, H., Saharawat, Y.S., Gathala, M., and Ladha, J.K. 2011. Impact of resourceconserving technologies on productivity and greenhouse gas emission in rice-wheat system. Greenhouse Gases: Science and Technology, 1, 261-277.

Pikul, J. L., and Aase, J. K. 1995. Infiltration and soil properties as affected by annual cropping in the northern Great Plains. Agronomy Journal, 87(4), 656-662.

Pramanik, P., Bandyopadhyay, K. K., Bhaduri, D., Bhatacharyya, R., and Aggarwal, P. 2015. Effect of mulch on soil thermal regimes-A review. International Journal of Agriculture, Environment and Biotechnology, 8(3), 645.

Rasmussen, K. J. 1999. Impact of ploughless soil tillage on yield and soil quality: a Scandinavian review. Soil and Tillage Research, 53(1), 3-14. Reicosky, D.C., 2015. Conservation tillage is not conservation agriculture. J. Soil Water Conserv. 103A-108A. http://dx.doi.org/10.2489/jswc.70.5.103a.

Riley, H. C. F., Bleken, M. A., Abrahamsen, S., Bergjord, A. K., and Bakken, A. K. 2005. Effects of alternative tillage systems on soil quality and yield of spring cereals on silty clay loam and sandy loam soils in the cool, wet climate of central Norway. Soil and Tillage Research, 80(1), 79-93.
Roldán, A., Caravaca, F., Hernández, M. T., Garcí, C., Sánchez-Brito, C., Velásquez, M., and Tiscareño, M. 2003. No-tillage, crop residue additions, and legume cover cropping effects on soil quality characteristics under maize in Patzcuaro watershed (Mexico). Soil and Tillage Research, 72(1), 65-73.

Saharawat, Y. S., Singh, B., Malik, R. K., Ladha, J. K., Gathala, M., Jat, M. L., and Kumar, V. 2010. Evaluation of alternative tillage and crop establishment methods in a ricewheat rotation in North Western IGP. Field Crops Research, 116(3), 260-267.

Saharawat, Y.S., Ladha, J.K., Pathak, H., Gathala, M., Chaudhary, N., and Jat, M. L. 2012. Simulation of resource-conserving technologies on productivity, income and greenhouse gas emission in rice-wheat system. Journal of Soil Science and Environmental Management, 3(1), 9-22.

Sauer, T. J., Clothier, B. E., and Daniel, T. C. 1990. Surface measurements of the hydraulic properties of a tilled and untilled soil. Soil and Tillage Research, 15(4), 359369. Sayre, K.D., Hobbs, P.R., 2004. The raised-bed system of cultivation for irrigated production conditions. In: Lal, R., Hobbs, P., Uphoff, N., Hansen, D.O. (Eds.), Sustainable Agriculture and the RiceWheat System. Ohio State University, Columbus, OH, USA, pp. 337-355.

Sharma, A. R., Jat, M. L., Saharawat, Y.S., Singh, V. P., and Singh, R. 2012. Conservation agriculture for improving productivity and resource-use efficiency: prospects and research needs in Indian context. Indian Journal of Agronomy, 57 (IAC Special Issue), 131-140.

Shaver, T. M., Peterson, G. A., Ahuja, L. R., Westfall, D. G., Sherrod, L. A., and Dunn, G. 2002. Surface soil physical properties after twelve years of dryland no-till management. Soil Science Society of America Journal, 66(4), 1296-1303.

Shukla, M. K., Lal, R., Owens, L. B., and Unkefer, P. 2003. Land use and management impacts on structure and infiltration characteristics of soils in the North Appalachian region of Ohio. Soil Science, 168(3), 167-177. 
Sidhu, H.S., Singh, M., Humphreys, E., Singh, Y., Singh, B., Dhillon, S. S., Blackwell, J., Bector, V. M., and Singh, S. 2007. The happy seeder enables direct drilling of wheat into rice straw. Australian Journal of Experimental Agriculture, 47, 844-854.

Silburn, D. M., Freebairn, D. M., and Rattray, D. J. 2007. Tillage and the environment in subtropical Australia-tradeoffs and challenges. Soil and Tillage Research, 97(2), 306-317.

Singh, K. K., Jat, A. S., and Sharma, S. K. 2005. Improving productivity and profitability of rice (Oryza sativa)-wheat (Triticum aestivum) cropping system through tillage and planting management. Indian journal of agricultural science, 75(7), 396-399.

Soane, B. D., and Pidgeon, J. D. 1975. Tillage requirement in relation to soil physical properties. Soil Science, 119(5), 376-384. Su, J. Zhang, W. Wu, D. Cai, J. Lv, G. Jiang, et al., Effects of conservation tillage practices on winter wheat water-use efficiency and crop yield on the Loess Plateau, China Agricultural Water Management, 87 (2007), pp. 307-314.

Teasdale, J. R., and Mohler, C. L. 1993. Light transmittance, soil temperature, and soil moisture under residue of hairy vetch and rye. Agronomy Journal, 85(3), 673-680.

Tomar, S. S., and Verma, O. P. 1985. Effect of irrigation and mulch on the performance of wheat planted on different dates. Zeitschrift für Acker-und Pflanzenbau, 154(4), 258266.

Unger, P. W., Langdale, D. W. and Papendick, R. I. 1988. Role of crop residues-improving water conservation and use. Cropping strategies for efficient use of water and nitrogen, vol. 51 (ed. W. L. Hargrove), Madison, WI: American Society of Agronomy. pp. 69-100. Voorhees, W. B. 1984. Relative effectiveness of tillage and natural forces in alleviating wheel-induced soil compaction. Soil Science Society of America Journal, 47(1), 129-133.

Wilson, R.G. and Jasa, P.J. 2007. "Ridge plant system: weed control. Institute of Agriculture and Natural Resources." University of Nebraska- Lincoln Extension. Wolff, P., and Stein, T. M. (1998). Water efficiency and conservation in agriculture: opportunities and limitations. Agriculture and Rural Development, 2, 2-20.

\section{How to cite this article:}

Vikas Rai, Pragati Pramanik, Pramila Aggarwal, Prameela Krishnan and Ranjan Bhattacharyya. 2018. Effect of Conservation Agriculture on Soil Physical Health. Int.J.Curr.Microbiol.App.Sci. 7(02): 373-389. doi: https://doi.org/10.20546/ijcmas.2018.702.049 